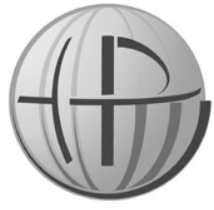

Horyzonty Polityki 2020, Vol. 11, No 35

OPEN ACCESS

\section{Dariusz KuboK}

http://orcid.org/0000-0003-3360-9667 Uniwersytet Śląski w Katowicach

Wydział Humanistyczny Instytut Filozofii

dariusz.kubok@us.edu.pl

DOI: $10.35765 / H P .1922$

\title{
Kilka uwag o modelach zetetycznych w filozofii polityki: Voegelin - Strauss
}

\section{Streszczenie}

CEL NAUKOWY: Celem badań będzie ogólne skonfrontowanie ze sobą dwóch modeli zetetycznych w obszarze filozofii polityki. Interesować mnie będą poglądy Erica Voegelina i Leo Straussa i ich nawiązania do filozofii greckiej. W efekcie tych dociekań ukazane zostaną nie tylko możliwości wieloaspektowego rozumienia filozofii polityki w antydogmatycznym duchu zetetycznym, lecz także różnice w modelach zetetycznych na bazie refleksji z zakresu filozofii polityki.

PROBLEM I METODY BADAWCZE: Artykuł zawiera rozważania metafilozoficzne odnoszące się do obszaru filozofii polityki. Wykorzystane zostaną przede wszystkim metody filozoficzne stosowane na metapoziomie w stosunku do dociekań z zakresu filozofii polityki.

PROCES WYWODU: Najpierw postaram się dookreślić frazę „model zetetyczny" na podstawie fragmentów dzieł Platona, Arystotelesa i Sekstusa Empiryka. W dalszej części wywodu przedstawię model zetetyczny Voegelina, opierając się na jego dziele Order and History oraz Straussa - Restatement on Xenophon's Hiero. Finalnie porównam ze sobą obie koncepcje.

WYNIKI ANALIZY NA UKOWEJ: Pomimo oczywistej wspólnoty zainteresowań tych dwóch myślicieli (konserwatyzm, normatywizm, radykalizm, szacunek dla filozofii greckiej), można ukazać zasadnicze odmienności w ich pojmowaniu filozofii jako zetetycznego procesu. Na podstawie tego porównania ujawniają się także inne metafilozoficzne problemy, wynikające z wyzwań filozofii polityki. 
WNIOSKI, INNOWACJE, REKOMENDACJE: Z przeprowadzonych badań wynika, że istnieje potrzeba głębszego przeanalizowania metod zetetycznych w najnowszej filozofii polityki. Pierwszym krokiem w tym celu będzie przemyślenie zetetycyzmu M. Oakeshotta.

\title{
SŁOWA KLUCZOWE:
}

filozofia, filozofia polityki, zetetyzm, krytycyzm, metafilozofia

\author{
Abstract \\ SOME COMMENTS ON ZETETIC MODELS \\ IN THE PHILOSOPHY OF POLITICS: \\ VOEGELIN - STRAUSS
}

RESEARCH OBJECTIVE: The aim of the research is to confront two zetetic models in the field of philosophy of politics. I am most interested in the views of Eric Voegelin and Leo Strauss and their references to ancient Greek philosophy. These inquiries will not only indicate the possibility of a multi-faceted understanding of the philosophy of politics in an anti-dogmatic zetetic spirit, but also the differences in zetetic models based on reflection in the field of philosophy of politics.

THE RESEARCH PROBLEM AND METHODS: The article contains metaphilosophical considerations related to the field of philosophy of politics. The primary methods used will be philosophical methods, applied at the meta level to inquiries in the field of political philosophy.

THE PROCESS OF ARGUMENTATION: First, I will try to specify the phrase "zetetic model" based on passages from Plato, Aristotle and Sextus Empiricus. In the further part of my argument, I will present Voegelin's zetetic model based on his book Order and History and Strauss' model based on Restatement on Xenophon's Hiero and compare both views.

RESEARCH RESULTS: Despite the fact that both these thinkers share common ideas (conservatism, normativism, radicalism, respect for Greek philosophy), there are fundamental differences in their understanding of philosophy as a zetetic process. This comparison also brings other metaphilosophical problems to light, resulting from the challenges of the philosophy of politics.

CONCLUSIONS, INNOVATIONS, AND RECOMMENDATIONS: The research shows that there is a need for a more in-depth and comprehensive examination of zetetic methods in recent philosophy of politics.

\section{KeYwORDS:}

philosophy, philosophy of politics, zeteticism, criticism, metaphilosophy 
Kilka uwag o modelach zetetycznych w filozofii polityki

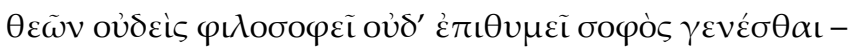

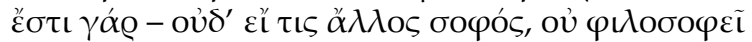

Platon, Uczta, 204a.

„Z bogów żaden nie filozofuje ani nie pragnie mądrości - on ją ma; ani żadna inna istota mądra nie filozofuje" (Platon, 1999, 204a). W Platońskiej opowieści o filozofie-Erosie z Uczty warto zwrócić uwagę na kluczową „pozycję" bohatera, czyli na „bycie pomiędzy” Dostatkiem

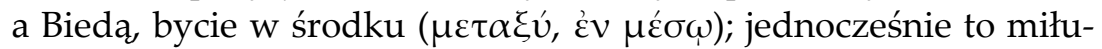
jące pragnienie jest poszukiwaniem i dążeniem w stronę mądrości. Żywioł filozoficzny rozpina się zatem między niewiedzą $(\dot{\alpha} \mu \alpha \theta \dot{\alpha} \alpha)$

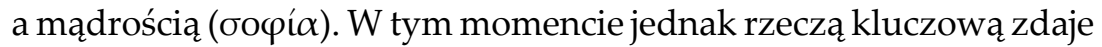
się być pouczenie Diotymy, że erotetyczna dążność filozofa nie tyle przejawia się w przedmiocie umiłowania, lecz w sposobie (funkcji) odnoszenia się do przedmiotu (204c). Owo odnoszenie wyraża cza-

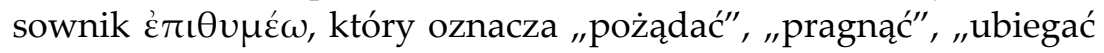

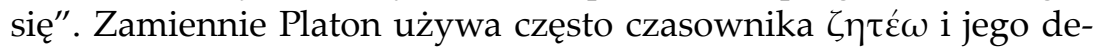
rywatów na określenie tego poszukiwania i dążenia ${ }^{1}$. Można zatem powiedzieć, że w tym ujęciu istotą filozofii jest proces zetetyczny rozumiany jako proces poszukiwania, dociekania, pragnienia czy też umiłowania mądrości, dobra, całości, tego, czego się nie ma albo jeszcze innej rzeczy. Jak nietrudno się domyśleć, tak „parasolowo" (określenie Hankinsona) pojęta filozofia jako proces zetetyczny (zetetycyzm) może przybrać różne formy i mieć różne funkcje (uwaga Diotymy), które będę nazywał modelami zetetycznymi. Ogólnie rzecz biorąc, wszelkie modele zetetyczne zakładają aktywistyczny, antydogmatyczny i opierający się na nadziei znalezienia (Peirce'owa koncepcja the rule of hope wpisana $\mathrm{w}$ projekt the long run ${ }^{2}$ ) sposób myślenia o filozofii, radykalnie odmienny od pozytywnodogmatycznego jej pojmowania jako stanu pewności w obliczu ostatecznych rozstrzygnięć. Zetetyczny charakter filozofii związany jest nie tylko

1 Zob. np. dialogi Laches (180c), Eutyfron (7a), Sofista (218 b), Polityk (262a), Fedon (65 a), Teajtet (196d), Eutydem (289e), Gorgiasz (457d), Menon (72a), Państwo (336e), Parmenides (133 a), Fileb (16d), Prawa (630e), Timajos (29d).

2 "We must therefore be guided by the rule of hope, and consequently we must reject every philosophy or general conception of the universe, which could ever lead to the conclusion that any given general fact is an ultimate one" (Peirce, 1931-1958, 1.405). 
z Platońskim jej rozumieniem. Warto odnieść się do tekstów Arystotelesa i Sekstusa Empiryka. Ten pierwszy pisze:

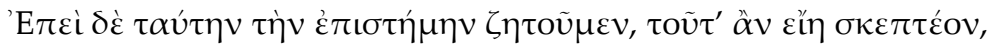

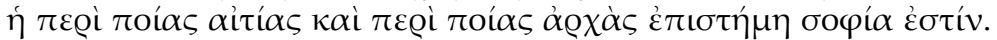
Skoro tedy poszukujemy takiej wiedzy, to należy zbadać, o jakich to przyczynach i zasadach musi być to wiedza, by była ona mądrością (Arystoteles, 1996, 982a, 4-6).

Działalność zmierzającą do ujęcia postaci wiedzy jest działalnością

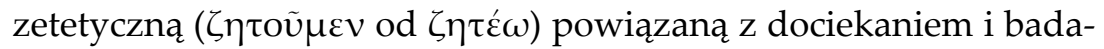

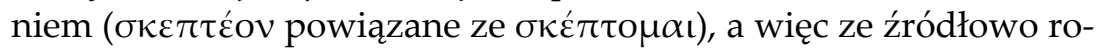
zumianym wysiłkiem sceptycznym w jego naturalnym, aktywistycz-

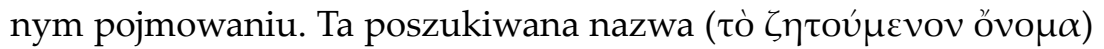

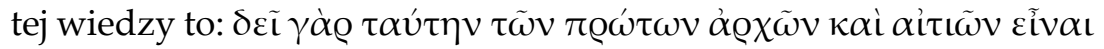

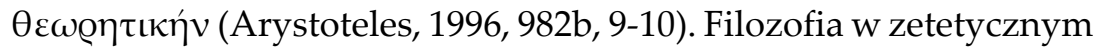
modelu Arystotelesowym (perspektywa metafilozoficzna) jest poszukiwaniem pierwszych zasad i przyczyn ${ }^{3}$. Sekstus Empiryk natomiast $\mathrm{w}$ Zarysach pyrrońskich $\mathrm{w}$ rozdziale zatytułowanym Пв@i $\tau \tilde{\eta} \varsigma$

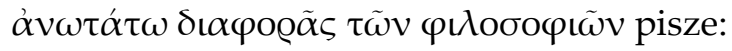

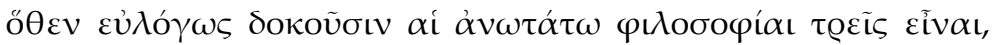

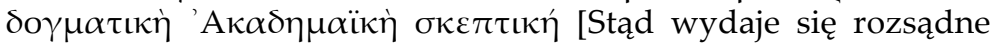
przyjąć, że są trzy najwyższe filozofie: dogmatyczna, akademicka i sceptyczna] (Sekstus Empiryk, 1958, I, 4).

Można przyjąć, że intencją Sekstusa było przedstawienie najwyższego czy też głównego rozróżnienia między filozofiami i podział ten uznawał on za zupełny. $Z$ kolei w paragrafie zatytułowanym

3 Warto zauważyć, że dla Arystotelesa postawa zetetyczna związana jest ze sceptyczną w jej źródłowym rozumieniu. Znamienny jest fakt, że dojrzałe koncepcje sceptyczne (Pyrron, akademicy, Cyceron, Sekstus Empiryk i ich epigoni) zaczynają pojmować wysiłek sceptyczny jako wyraz efektycyzmu, epechizmu (słownik Montaigne'a) lub aporetyzmu. Ewentualnie można rozumieć sceptycyzm tak jak Odo Marquard, który odchodząc od aporetyzmu i negatywnego dogmatyzmu, sceptycyzm rozumie jako postawę antyarystotelesową: ",Sceptykami zatem wcale nie są ci, którzy z zasady nic nie wiedzą; oni nie znają jedynie nic pryncypialnego; sceptycyzm nie jest więc apoteozą bezradności, ale tylko rozstaniem z filozofia pierwszych zasad" (Marquard, 1994, s. 18-19). 


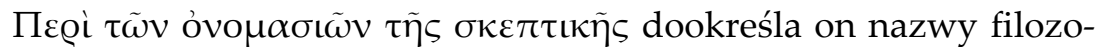
fii rozumianej jako myśl sceptyczna, która stanowi negację filozofii dogmatycznej w obu jej odsłonach: jako dogmatyzm (czyli w istocie pozytywny dogmatyzm) oraz akademizm (czyli w istocie negatywny dogmatyzm $)^{4}$. Dla dalszych analiz kluczowa jest pierwsza z wymie-

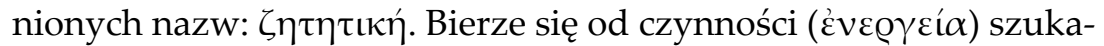

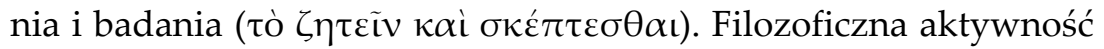
antydogmatyczna (jako alternatywa negacji pozytywnego dogmatyzmu i negacji negatywnego dogmatyzmu) zostaje w pierwszej kolejności ujęta w perspektywie sceptycznej (w tym źródłowym sensie) i zetetycznej.

Celem niniejszych badań będzie ogólne skonfrontowanie ze sobą dwóch wybranych modeli zetetycznych w obszarze filozofii polityki. Nie będzie zatem chodzić o szczegółowe ich porównanie, ale o ogólne ich zestawienie w celu ukazania nie tylko możliwości wieloaspektowego rozumienia filozofii polityki w [antydogmatycznym] duchu zetetycznym, lecz także - a może przede wszystkim - różnic $\mathrm{w}$ modelach zetetycznych na przykładach wziętych z zakresu filozofii polityki. Ogólnie rzecz biorąc, poniższe uwagi mogą być kwalifikowane jako rozważania metafilozoficzne w stosunku do filozofii polityki. Z tego względu posługiwać się będę metodami filozoficznymi stosowanymi na metapoziomie w stosunku do rozważań z zakresu filozofii polityki. Spróbuję skontrastować ze sobąna podstawie tekstów źródłowych - modele zetetyczne w filozofii polityki prezentowane przez Leo Straussa i Erica Voegelina. Wybór ich jest po części arbitralny, choć myślicieli tych łączą ogólnie pojęte przekonania konserwatywne ${ }^{5}$. Nie one jednak będą dla mnie

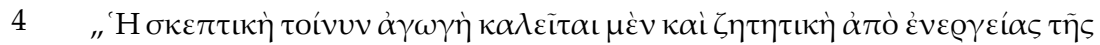

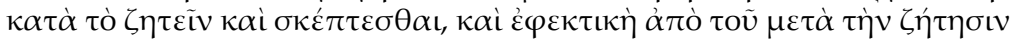

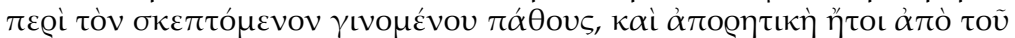

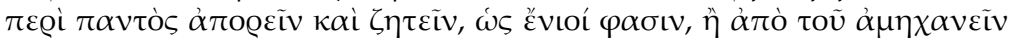

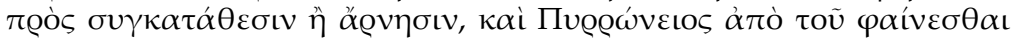

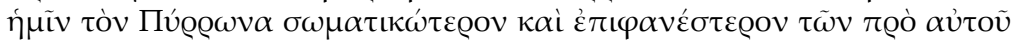

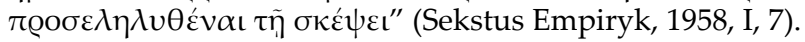

5 Nie bez znaczenia jest fakt, że urodzili się w przeciągu zaledwie dwóch lat (1899-1901). Nie będzie moim celem porównywanie ich koncepcji, jest to zadanie na osobne studium. Ogólnie tylko zaznaczyć trzeba, że łączy ich szeroko rozumiany konserwatyzm, a raczej wybrane cechy "parasolowego" terminu konserwatyzm, i - co dla mnie szczególnie istotne - specyficzny 
interesujące, ale raczej to, że pomimo pewnej wspólnoty przekonań ich propozycje metafilozoficzne się różnia, a już na pewno inaczej rozłożone są w nich akcenty i priorytety. Główną zasadą inkluzji myślicieli do niniejszego opracowania był fakt ich niemarginalnego związku z dziedzictwem myśli greckiej, a przede wszystkim ich analizy expressis verbis nawiązujące do filozoficznej postawy zetetycznej. Jednym z elementów tej konfrontacji będzie także przeanalizowanie odwołań tych badaczy do fragmentów antycznego dziedzictwa filozoficznego. Można zatem powiedzieć, że zadaniem stawianym w tym artykule nie jest porównanie poglądów obu tych myślicieli, lecz krytyczny i metafilozoficzny namysł nad dwoma modelami zetetycznymi w filozofii polityki w XX wieku. Ze względu na ograniczony zakres formy artykułu te dwa modele zetetyczne uzyskam głównie z dwóch wysoce reprezentatywnych fragmentów każdego $\mathrm{z}$ tych myślicieli (oba z lat pięćdziesiątych XX wieku).

\section{ERIC VOEGELIN}

Pierwszy fragment pochodzi z trzeciego tomu jego monumentalnego działa Order and History (Voegelin, 2000), a konkretnie z tej jego części, która dotyczy Platona. Przedmiotem namysłu dla Voegelina jest tutaj dialog Państwo, a w jego ramach pojawia się ustęp zatytułowany

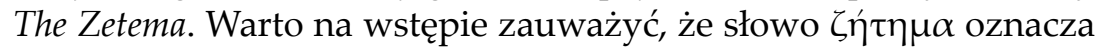
„rzecz poszukiwaną" i „poszukiwanie”, , przedmiot dociekania” czy

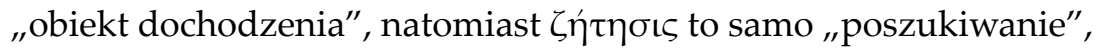
"dociekanie", „badanie”, ,sprawdzanie”, ,dochodzenie”, a nawet "śledztwo". Platonowi chodzi o poszukiwanie dobrego porządku polis. Voegelin słusznie (wbrew np. Popperowi) odczytuje tę procedurę jako dociekanie tego, co najlepsze, a nie jako kreowanie ideału mogącego się zlewać z utopią. Nie mamy tu do czynienia z Platonem pojmowanym jako political ideologue, ale z filozofem. Podkreślić jednak trzeba, że filozoficzny model zetetyczny w ujęciu Voegelina zorientowany jest na cel zetetyczny i ze względu na niego jest pojmowany

antydogmatyzm, krytycyzm modernizmu przy użyciu klasyków (głównie myślicieli greckich), a także specyficzny radykalizm oraz normatywizm. 
Kilka uwag o modelach zetetycznych w filozofii polityki

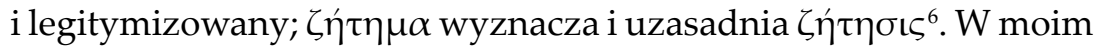
przekonaniu projekt zetetyczny określony mianem the Zetema bardziej odpowiada z metafilozoficznego punktu widzenia Voegelinowi, niż gdyby został nazwany zetesis, $\mathrm{z}$ tego powodu, że proces poszukiwania interesuje go wraz z poszukiwanym przedmiotem; mówiąc inaczej, poszukiwanie legitymizuje się zadanym jego celem. Alternatywną opcją byłoby takie rozumienie wysiłku zetetycznego, gdzie poszukiwanie nie ma wyznaczonego kresu ani punktu dojścia. Oczywiście nie będę analizował teraz ani Platońskiego tropienia dobrej polis w Państwie, ani specyfiki wykładni tego procesu przez Voegelina, ale przyjrzę się metafilozoficznie samemu projektowi proponowanego modelu zetetycznego.

Droga zetetyczna (the zetema) zostaje anabastycznie określona jako "conceptual illumination of the way up from the depth of existence" (Voegelin, 2000, s. 137). Skłonny byłbym tymczasowo traktować zgodnie ze swoiście rozumianą zasadą $\mu \varepsilon \tau \alpha \xi \hat{v}$ - illumination ani nie jako „wyjaśnienie”, ani nie jako „oświecenie”, tylko jako „rozjaśnienie", w tym wypadku pojęciowe. Voegelin przez zetema rozumie zarówno samo dociekanie (inquiry), jak i rozjaśniające dociekanie (illuminating inquiry, Voegelin, 2000, s. 138) ${ }^{7}$. Kluczową jednak sprawą jest przyjęcie przez niego dwóch orientujących zetetyczną podróż wskaźników: (1) punktu wyjścia i (2) kierunku dążenia. Punkt wyjścia to pierwotna sytuacja określona jako the depth of existence [głębia egzystencji], a nawet jako the despair of the depth [rozpacz głębi] (s. 139) lub the darkness of the depth [ciemność głębi] (Voegelin, 2000, s. 150). To doświadczenie głębi nie jest doświadczeniem pustej wolności wybo$\mathrm{ru}$; filozofia - jako badanie porządku - wyrasta z tej głębi i obejmuje doświadczenie kierunku, ukazując tym samym możliwość, a przez to nadzieję. Warto podkreślić, że wysiłek zetetyczny w głębi egzystencji jest niejako źródłowo sformatowany wzorcem życia i społecznym naciskiem. Kierunek z kolei określony jest jako droga z ciemności to height and light [do wysokości i światła] (s. 150), droga from the depth upward [z głębi wzwyż] (Voegelin, 2000, s. 137).

6 Czasami jednak można odnieść wrażenie, że Voegelin przez the zetema rozumie to samo, co oznaczone jest mianem the inquiry (Voegelin, 2000, s. 137),

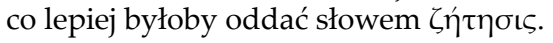

7 Por. Webb, 1978, s. 95-122. 
Voegelin stara się podkreślić, że the zetema jako rozjaśniające dociekanie nie jest zewnętrzne, ale wyrasta z pierwotnego doświadczenia. Można powiedzieć, że w ramach ogólnie pojętej procedury zetetycznej dokonuje się przejście od zakotwiczonego w doświadczeniu pierwotnym poszukiwania (zetesis) do badania czy też dociekania (zetema) o charakterze kierunkowym. Pierwotna ciemność głębi nie jest absolutną ciemnością, o czym świadczy poszukiwawczy aspekt doświadczenia zamieniający się od wewnątrz w proces rozświetlania duszy, w swoistą - jak ładnie określa to Voegelin - luminosity of the depth. Droga ta może być ujęta jako droga od doświadczenia głębi do analizy tych doświadczeń, do interpretacji swej głębi (Voegelin, 2000, s. 138). W tym miejscu pojawia się pewna konfuzja. Czy w istocie Voegelin przyjmuje taki model zetetyczny (jako zetema - przedmiot poszukiwania i poszukiwanie samo), który proces zetetyczny podporządkowuje celowi, czy proces ten jest pojęty jako self-illumination of the soul (Voegelin, 2000, s. 139)? Pytanie to można wyrazić inaczej, czy wyznaczony kierunek zakłada określenie celu, nawet nieprecyzyjne? Czy kierunek określany mianem „wzwyż” nie zakłada już jakiejś góry i dołu? Aby rozjaśnić ten problem można odwołać się do dwóch sugestii zaczerpniętych z Voegelina. Pierwszą jest jego stwierdzenie, że "głębia doświadczenia nie jest beznadziejną nocą jakieś światło świeci w ciemności" (Voegelin, 2000, s. 138). To światło jest więc dane, obecne, a nie zadane czy też odszukane. Druga sugestia wiąże się ze stwierdzeniem Voegelina, że filozoficzna sytuacja Platona jest w istocie sytuacją Heraklitejskiego zetesis (Voegelin, 2000, s. 138). W moim przekonaniu sytuacja Voegelina też jest sytuacją Heraklita.

Aby wyrazić wspaniałą prostotę zetetycznego procesu filozoficz-

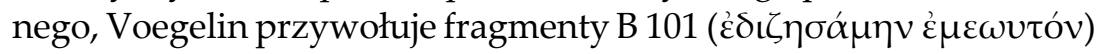

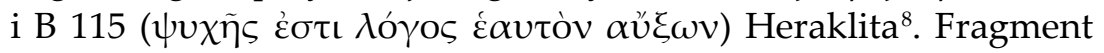
pierwszy, niezależnie od tego, czy jest bezpośrednią odpowiedzią na wezwanie bóstwa z Delf ${ }^{9}$, sugeruje, że Heraklit badał samego siebie.

8 Diels/Kranz, 1985, 21 B 101 i B 115.

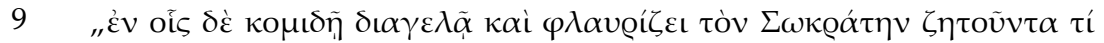

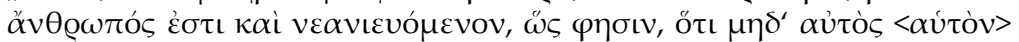

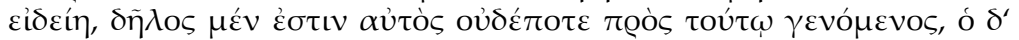

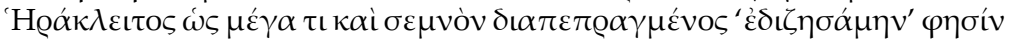

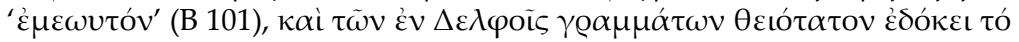

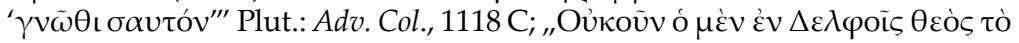


Efektów tego badania w tym fragmencie nie ma. Voegelin odnajduje te rezultaty w B 115, gdzie efektem tym jest samopowiększający się Logos. Te dwa fragmenty Heraklita faktycznie mają wydźwięk zetetyczny, przy czym studzony on być musi nie tylko możliwą wymową fragm. B 101 jako dokonanego (a nie ciągłego) badania, ale całym mnóstwem wypowiedzi Heraklita, w których prezentuje się on jako filozof wyróżniony epistemicznie, a zatem mający umiejętność, choćby częściowa, wsłuchania się w Logos. Trop delfijski korespondowałby z komentarzem Voegelina, że podobną prostotę zetetyczną odnaleźć można w Prologu Ewangelii św. Jana, gdzie Logos Boga jest światłem człowieka. Można odnieść wrażenie, że właśnie takie zespolenie obu tradycji kształtuje postrzeganie przez Voegelina filozoficznego procesu zetetycznego. Illumination jako rozjaśnienie, o którym była mowa, wydaje się teraz bliższe nie „wyjaśnieniu”, lecz „oświeceniu”. Proces zetetyczny w ujęciu Voegelina można ujmować w perspektywie animi intentio św. Augustyna, a filozofia zdaje się być dla Vogelina tym, czym była - w jego ujęciu - dla Platona: wspinaniem się człowieka w stronę Boga, w kierunku zbawienia ${ }^{10}$. Można powiedzieć, że $\mu \varepsilon \tau \alpha \xi \hat{v}$ pojęte jako In-Between nie wyraża tylko łączącego charakteru tzw. „pomiędzy" doczesnością a transcendencją ale także kierunkowe „,ku”.

\section{LEO STRAUSS}

Drugi fragment pochodzi z rozprawy Leo Straussa Restatement on Xenophon's Hiero ${ }^{11}$, będącej odpowiedzią na krytykę jego badań nad

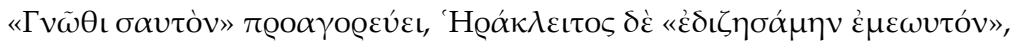

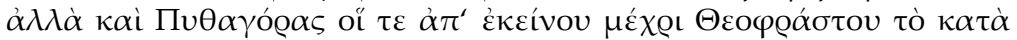

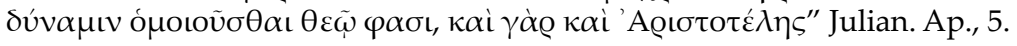

10 "The philosopher is man in the anxiety of his fall from being, and philosophy is the ascent toward salvation for Everyman, as the pamphylic componends of the myth suggest. Plato's philosophy, therefore, is not $a$ philosophy, but the symbolic form in which a Dionysiac soul expresses its ascent to God" (Voegelin, 2000, s. 124-125). Zob. także Webb, 1981, s. 123-128. M.P. Morrissey silnie akcentuje nieskończoność procesu zetetycznego w ujęciu Voegelina. Zob. Morrissey, 1994, s. 89-90 i 117. Trzeba jednak zdawać sobie sprawę z tego, że prowadzi to do tezy o niemożliwości osiągnięcia celu, co z kolei jest wyrazem negatywnego dogmatyzmu.

11 Zob. Strauss 2000b. Por. Patard 2008. 
Ksenofontowym dziełem 'IÉ $\omega \omega \nu$ (On Tyrrany z 1948 roku), którą przeprowadzili przede wszystkim Eric Voegelin i. Alexandre Kojève. Nie wchodząc teraz $\mathrm{w}$ treść tej polemiki ${ }^{12}$, warto podkreślić, że jedną z tez Kojève'a, która doczekała się repliki ze strony Straussa, było przekonanie, iż de facto nie ma tak naprawdę istotnej różnicy między politykiem a filozofem, obaj bowiem łakną uznania. Zagadnienie to $\mathrm{w}$ dalszym toku analiz wiąże się z zagadnieniem sekty. Jak wiadomo, Strauss zakładał, że filozof potrzebuje przyjaciół, bo wiedza wykuwa się $\mathrm{w}$ intersubiektywnej debacie filozofów ${ }^{13}$. Istotna obawa związana jest jednak z tym, aby grono przyjaciół nie zamieniło się w sektę konserwującą własne przesądy. W tym kontekście właśnie pojawia się pytanie Straussa: czy musimy wybrać sektę? Jednocześnie wyraża on sprzeciw wobec sugestii Kojève'a, w myśl której filozofia musi zakładać jakieś subiektywne pewności. To one - nie będąc obiektywnymi prawdami - po prostu są przesądami. Strauss natomiast twierdzi, że "filozofia w źródłowym znaczeniu tego słowa nie jest niczym innym, jak wiedzą o swojej niewiedzy" (Strauss, 2000b, s. 196). Subiektywna pewność tej niewiedzy odpowiada i pokrywa się z domniemaną „obiektywną prawdą" tej pewności. Strauss sugestywnie wyraża tę myśl: „But one cannot know that one does not know without knowing what one does not know" (Strauss, 2000b, s. 196). Chodzi więc o to, że filozofia w swojej istocie nie musi kierować w stronę pozytywnego dogmatyzmu utrwalanego na przykład węwnętrznymi więzami sekty, ale też nie musi się zapadać w odrętwiający stan negacji wszelkich odpowiedzi (negatywny dogmatyzm), który może przybrać charakter postawy antyfilozoficznej. W efekcie Strauss stwierdza, że impotencja zarówno dogmatyzmu, jak i sceptycyzmu ,,jest jedynym możliwym uzasadnieniem filozofii, która jako taka nie jest ani dogmatyczna, ani sceptyczna, a tym bardziej «decyzjonistyczna»,

12 Na temat polemiki Straussa i Kojève'a zob. Grant, 1964, s. 45-72; Emberley, Cooper, 2004; McAllister, 1997; Drury, 1994, s. 143-160; Armada, Górnisiewicz, 2007; Burns, Frost 2016. Fascynujące dzieje dyskusji pomiędzy Straussem a Voegelinem znaleźć można w Emberley, Cooper, 2004.

13 „Prześladowanie nie może przeszkodzić w niezależnym myśleniu, gdyż jest dziś tak samo prawdą jak dwa tysiące lat temu, że można bezpiecznie powierzyć prawdę życzliwym i godnym zaufania znajomym, a dokładniejrozumnym przyjaciołom" (Strauss, 1998, s. 108). 
ale zetetyczna (lub sceptyczna w źródłowym sensie tego terminu)" (Strauss, 2000b, s. 196) ${ }^{14}$.

Choć Strauss nie pisze o tym wprost, wyraźnie ma tu na myśli przytoczony powyżej Sekstusowy podział filozofii, o czym najlepiej świadczy właśnie utożsamienie filozofii z postawą zetetyczną (zetetic) czy też ze sceptyczną (w źródłowym znaczeniu słowa oKé $\psi \iota \varsigma)^{15}$. Zastanawiające i po części niespójne jest opisanie zniesionych określeń filozofii. O ile wykluczenie dogmatycznego charakteru filozofii nie budzi wątpliwości, o tyle zastosowanie słowa „sceptyczna” w odniesieniu do odrzuconej wersji filozofii może wydawać się dziwne, szczególnie że poprawna forma filozofii jest określona zaledwie wers dalej sceptyczną w źródłowym sensie tego terminu. Czytelnik oczekiwałby raczej określenia „, akademicka”, zgodnie z tradycją nawiązującą do Sekstusa. Można przyjąć, że Strauss (1) od różnia filozofię sceptyczną i filozofię sceptyczną w źródłowym sensie tego terminu lub (2) odwołuje się do takiej tradycji filozoficznej, która sceptycyzm (już nie źródłowo) pojmowała jako akademizm (negatywny dogmatyzm), ewentualnie postrzegała jako radykalną i globalną formę wątpienia. Na ten drugi trop wskazuje przywołany w kontekście tego rozróżnienia Pascal. Nie wchodząc w szczegółową analizę złożonego problemu sceptycyzmu Pascala, trzeba tylko zauważyć, że myśliciel ten, bazując głównie na ustaleniach Kartezjusza i Montaigne'a, ukazywał głównie niepewność poznania. Jednocześnie starał się znaleźć drogę pomiędzy dogmatyzmem a skrajnym sceptycyzmem. „Cierpimy na niemoc dowiedzenia, niezwalczoną dla całego dogmatyzmu. Mamy poczucie prawdy, niezwalczone dla całego pirronizmu" (Pascal, 1972, s. 273). Pascal, za Montaigne'm, traktuje sceptycyzm jako pyrronizm,

14 W tym miejscu mowa jest o zastąpieniu filozofii rozumianej jako decisionist przez jej pojmowanie $\mathrm{w}$ duchu zetetic. $\mathrm{W}$ innym miejscu Strauss pisze: „Philosophy in its original sense is disputative rather than decisive" (Strauss, 2006, s. 148).

15 L. Strauss wspomina o tym już w rozprawie Farabi's Plato: „It is the way leading to that science rather than that science itself: the investigation rather than the result. Philosophy thus understood is identical with the scientific spirit 'in action,' with oké $\psi\llcorner\varsigma$ in the original sense of the term, i. e. with the actual quest for truth which is animated by the conviction that that quest alone makes life worth living, and which is fortified by the distrust of man's natural propensity to rest satisfied with satisfying, if unevident or unproven, convictions" Strauss, 1945, s. 393). 
czyli jako wątpienie wątpiące nawet o sobie samym (Pascal, 1962, s. 86). Strauss, tak jak Pascal, nie chce się zgodzić na skrajność obu stanowisk: dogmatyzmu pozytywnego i sceptycyzmu jako pyrronizmu, a nawet negatywnego dogmatyzmu; wybiera zatem drogę pomiędzy, ale to „pomiędzy" ma zupełnie inny charakter niż $\mu \varepsilon \tau \alpha \xi \dot{v}$ Voegelina. O ile u tego ostatniego $\mu \varepsilon \tau \alpha \xi u ́$ ma funkcję łączenia, o tyle powołanie się Straussa na Pascala może być ryzykowne. Ten ostatni bowiem, (1) traktuje sceptycką izosteniczną neutralność jako przejście na pozycje pyrrońskie (Pascal, 1972, s. 438), wykluczając tym samym możliwość bycia pomiędzy, swoiste $\mu \varepsilon \tau \alpha \xi \hat{v}$, (2) rozumie sceptycyzm, bazujący na niepewności, jako otwarcie się na wiarę i ukorzenie się przed Bogiem. W moim przekonaniu nie tyle chodzi o irracjonalizm Pascala (Ziemińska, 2013, s. 236), ani o jego racjonalizm częściowy (Kleszcz, 2011, s. 159), ale o dogmatyzm lub dogmatycznie założony cel procedury zetetycznej, nie dającej się pogodzić ze źródłowo rozumianym sceptycyzmem jako zetetycyzmem, dla którego poszukiwanie ma - jeśli można tak powiedzieć - charakter otwarty, a nie zniewolony wyznaczonym dogmatycznie celem.

Leo Strauss definiuje filozofa następująco: „Filozof zatem przestaje być filozofem w momencie, gdy «subiektywna pewność» rozwiązania staje się silniejsza niż jego świadomość problematycznego charakteru tego rozwiązania" (Strauss, 2000b, s. 196). Takie rozumienie filozofa upoważnia do traktowania go w swojej istocie jako antydogmatyka ${ }^{16}$ o nastawieniu zetetycznym czy też erotetycznym (raczej w duchu greckim niż nowożytnym). Odwrotnością filozofa jest sekciarz (sectarian). Strauss trafnie zaznacza, że rzeczą kluczową dla filozofii jest umiejętność nieulegania niebezpieczeństwom wynikającym z atrakcyjności rozstrzygających rozwiązań. Warto dodać, że utrzymywanie takiego czujnego stanu zetetycznego napięcia jest

16 Widać to szczególnie, gdy weźmie się pod uwagę definicję dogmatyzmu w ujęciu Alvina Plantingi. Pisze on: „In one use, to say of someone that she is a dogmatist is to say that she holds her views more strongly then is appropriate, more strongly then the evidence warrants, for example; alternatively, it is to say that she holds her views uncritically, without paying sufficient heed to objections and alternatives, or to the limitations of human reason (see Kant). 'Dogmatism' is therefore an indexical term; whether you properly apply it to a given doctrine or belief depends upon where you yourself stand" (Plantinga, 1992, s. 108-109). 
niesłychanie trudne, łatwo bowiem można „stoczyć się" albo w stronę pozytywnodogmatycznej akceptacji ostatecznych rozwiązań, albo w stronę negatywnodogmatycznego przeświadczenia o wiecznym niespełnieniu. Przykład z Pascalem pozwala przypuszczać, że Strauss miał z tym kłopot ${ }^{17}$; jego również pociaggała filozoficzna, niesekciarska, ale jednak wyidealizowana postawa Sokratesa, którego przy bliższym oglądzie (nawet na podstawie tylko dialogów Platona, a nie dzieł Ksenofonta) można odczytywać jako myśliciela co najmniej przychylającego się ku pewnym rozwiązaniom, a tym samym słabo maskującego czujny stan nieulegania powyżej wskazanym niebezpieczeństwom (np. kierunkowy charakter prowadzenia rozmowy). Na poziomie normatywnym Strauss (po grecku) traktuje filozofię jako miłość, pożądanie, erotetyczne pragnienie całości lub całościowego oglądu ${ }^{18}$. Trzeba przyznać mu rację, że filozofia w swojej najgłębszej warstwie jest miłością a z miłości nie trzeba się tłumaczyć. Niemniej jednak zetetycznej miłości filozoficznej nie powinna jednak przeszkadzać nawet szczera miłość do Greków. Sam Strauss swoje rozważania na ten temat wieńczy znamiennym i sugestywnym zwrotem, ostrzegającym przed przynależnością do sekty: „Amicus Plato" (Strauss, 2000b, s. 196). Sceptyczna (w źródłowym znaczeniu tego słowa) rekomendacja powinna być uzupełniona o zwrot: Amicus Sokrates.

17 Trudno zgodzić się z konkluzją Haralda Bluhma, że myślenie Straussa było zetetyczne tylko częściowo, bo może to oznaczać, że można być myślicielem np. zetetycznym i dogmatycznym, każdym w jakiejś części. Powiedziałbym raczej, że trudno było mu utrzymywać kurs pomiędzy Skyllą dogmatyzmu a Charybdą globalnego pyrronizmu. W dużej mierze odpowiadała za to jego miłość, miłość do Greków, a w szczególności do wyidealizowanej i traktowanej zbyt mało krytycznie postaci i postawy Sokratesa, wysnutej z jednostronnej analizy świadectw doksograficznych. Warto byłoby szczegółowo przeanalizować stosunek Straussa do Sokratesa. Zob. Bluhm 2017, s. 145-160. Na temat Platońskiej filozofii polityki w ujęciu Straussa zob. Strauss, 1983, natomiast w kwestii recepcji myśli L. Straussa zob. Armada, 2011.

18 Strauss skłonny jest twierdzić, że każde partykularne pojmowanie odwołuje do świadomości całości; to, co partykularne jest cząstkowe i prowadzi do tego, co całościowe. Można jednak mówić, zamiast o świadomości całościowej, czy otwartości na całość, po prostu o świadomości kontekstu i próbach zrozumienia przyjmowanych ram pojęciowych. Całość bowiem wydaje się być zmienna i relatywna w perspektywie danego oglądu, a nie wykończona jako zasób, ideał czy też idea normatywna. 


\section{PODSUMOWANIE}

Filozofia jest dla Straussa aktywnością radykalną z racji zarówno

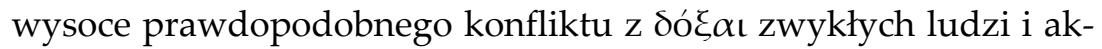
torów politycznych, oglądu całościowego, jak i swoistej obojętności wobec doraźności zawłaszczającej wszelką perspektywę oglądu. Filozof musi ćwiczyć się w umieraniu dla świata, z którego wyszedł i w którym częściowo tylko tkwi oraz jednocześnie powinien podsycać pragnienie pójścia dalej w stronę bytów wiecznych i problemów wieczystych ${ }^{19}$. Ten proces zetetyczny wydawał się mieć pierwotnie silny rys Sokratejski, zdaje się jednak, że - dzięki doprecyzowaniu

19 Warto w tym miejscu wspomnieć o propozycji Michaela Oakeshotta. Badacz ten, dzieląc wiele poglądów z oboma tu analizowanymi myślicielami, w sposób interesujący odróżnia się od nich w charakterze myślenia o filozofii (w tym o filozofii polityki) jako procesie zetetycznym. Punktem wyjścia w postępowaniu filozoficznym - pisze w eseju Philosophy of Politics - jest wiedza skażona niewiedza, a sam zetetyczny proces jest procesem podważania, nietolerującym punktów odniesienia, które mogłyby go stopować; filozofia jest zatem procesem radykalnie burzycielskim. W celu jego zobrazowania Oakeshott przyrównuje aktywność filozoficzną do wchodzenia na wieżę, która na każdym piętrze ma wiele okien. W miarę wspinania się na wyższe piętra wieży zmieniają się widoki i sukcesywnie ukazują się rzeczy, które wcześniej nie były dostrzegalne. Istotą wysiłku filozoficznego jest ciągła gotowość kroczenia dalej, podczas gdy inni zatrzymują się na jakimś poziomie. Taki obraz filozofii jako zetetycznej podróży akceptowaliby wszyscy trzej myśliciele, nawet $\mathrm{z}$ fundamentalną specyfikacją ich pojmowania zetetycyzmu jako drogi anabastycznej. Oakeshott jednak nie akcentuje kwestii ciągłej gotowości pójścia dalej ani skłonności do wspinaczki lub jej braku, ale chęć bądź niechęć zabrania ze sobą na wyższe piętra ustalonych i zapamiętanych widoków z niższych pięter, które determinują widok aktualny. Istotą filozofii jest całkowite zastępowanie widoku z niższego piętra widokiem z wyższego - teoretyczne burzycielstwo radykalne. Dla filozofa-wspinacza niepamięć wiąże się z permanentną chęcią kroczenia naprzód; wieża ta nie ma szczytu albo, należałoby powiedzieć lepiej, wspinacz nigdy nie wie, czy go już osiągnął. „Filozofia może być zatem postrzegana jako nieskrępowana działalność refleksyjna; wszyscy bylibyśmy filozofami, gdyby tak łatwo nie rozpraszało naszej uwagi to, co ujrzeliśmy na początku". (Oakeshott, 1999, s. 125). Interesujący problem porównania koncepcji filozofii Oakeshotta z propozycjami Voegelina i Straussa zostanie podjęty przeze mnie w osobnym studium. W tym miejscu warto tylko odwołać czytelnika do interesujących w tym zakresie tekstów Oakeshotta. Zob. Oakeshott, 1962; Oakeshott, 1993; Oakeshott, 1996. Na temat źródeł i antecedencji poglądów M. Oakeshotta, w szczególności dziedzictwa sceptycznego, zob. Coats, Jr., 2000; Gerencester, 2000; Wood, 1959; Tseng, 2003; Laursen, 2005; Botwinick, 
jego charakteru w duchu anabastycznym jako drogę w górę - ostatecznie przybrał postać Platońską w wersji zbliżonej do wykładu Diotymy z Uczty. Można by ten model rozważań filozoficznych

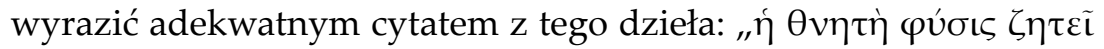

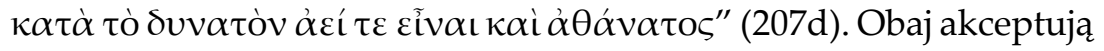
Platoński model zetetyczny, przy czym subtelne różnice pomiędzy nimi są takie, jak pomiędzy postawą i projektem Sokratesa z Państwa (Voegelin) a wizją Diotymą z Uczty (Strauss). Sokrates z dialogów Platona i Diotyma to aktorzy odkrywający spektakl napisany przez twórcę Akademii i wyrażający jego wizję filozofii ${ }^{20}$. A więc jednak: Amicus Plato.

Obaj myśliciele są Platońscy, ale do tego platonizmu dochodzą różnymi drogami. Gdyby odwoływać się do wcześniejszych niż Platon koncepcji filozoficznych, to w moim przekonaniu Voegelinowi najbliżej jest do zetetycznego modelu filozofii prezentowanego przez Heraklita, natomiast Straussowi do postawy zetetycznej Sokratesa, ale Sokratesa Platońskiego. Poza tym zasadnicze różnice związane są chyba z ich pojmowaniem filozofii. Obaj zetetycznie pojmują ją jako drogę - drogę radykalną i - mówiąc językiem Parmenidesa - daleką od ludzkiego, ubitego doksalnymi przekonaniami, traktu. Voegelin raczej skupia się na celu lub przynajmniej kierunku zetetycznych

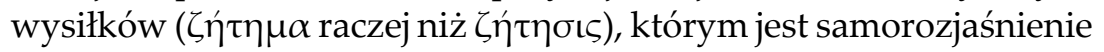

2011; Leszczyński, 2012; Orsi, 2015; Kubok, 2018. Na temat związków Straussa i Oakeshotta zob. Devigne, 1996.

20 Warto przypomnieć, że E.N. Tigerstedt dzieje interpretacji platonizmu ujął jako oscylację pomiędzy podejściem dogmatycznym a sceptycznym; to pierwsze traktuje filozofię Platona jako określoną doktrynę czy też system, to drugie z kolei akcentuje bezkonkluzywność dialogów lub sceptyczny czy też agnostyczny (a nawet negatywno-dogmatyczny) charakter dalszych losów Akademii (od Arkezyalosa); zob. Tigerstedt, 1977. Przykładem drogi pośredniej jest Luigi Stefanini, którego wykładnia „,konstruktywnego sceptycyzmu” zdaje się odpowiadać powyżej wskazanemu modelowi zetetycyzmu, dla którego schematem przewodnim jest Uczta. Filozofia w tej wykładni jest rozumiana właśnie jako aktywność erosa, czyli nienasycony trud poszukiwania i dociekania. Poza tym antydogmatyczne podejście krytyczne Platona widać zarówno w wymiarze treściowym (problem granic poznawczych człowieka), jak i metodycznym (metoda elenktyczna, hipotetyczna czy też aporetyczna; zob. Stefanini, 1932-1935. 
duszy przez wzrost jej Logosu ${ }^{21}$, Strauss natomiast akcentuje motyw zetetycznego dążenia jakim jest miłość sama (Eros) i analizuje istotę dążenia zetetycznego, która ukazuje filozofię jako sztukę życia

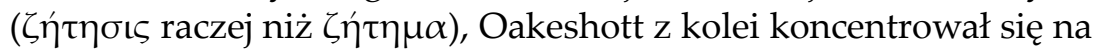
istocie parcia naprzód z wyłączeniem pamięci. Trzeba przyznać, że porównanie modeli zetetycznych obecnych u tych dwóch myślicieli pozwala jednocześnie porównać ich poglądy z nowej (zetetycznej) perspektywy, jak i ukazać metafilozoficzne problemy w świetle zderzenia ze sobą koncepcji z zakresu filozofii polityki. Kolejnym wyzwaniem badawczym powinna być próba znacznie szerszego opracowania metod zetetycznych w najnowszej filozofii polityki.

\section{Bibliografia}

A Greek-English Lexicon (1996). Compiled by H.G. Liddell, R Scott. Revised and Augmented Throughout by Sir H.S. Jones, with the assistance of Roderick McKenzie. Oxford: Clerendon Press.

Armada, P. (2011). Boże Prawo i ludzki potencjał: w stronę rozważań problemu teologiczno-politycznego. Horyzonty Polityki, 2 (2), 161-178.

Armada, P., Górnisiewicz A. (2007). Leo Strauss i Aleksandre Kojève: Wprowadzenie do debaty myślicieli. Politeja, 8, 49-96.

Arystoteles (1996). Metafizyka, t. 1-2. Oprac. M.A. Krąpiec, A. Maryniarczyk na podstawie tłum. T. Żeleźnika. Red. A. Maryniarczyk. Lublin: Redakcja Wydawnictw KUL.

Bluhm, H. (2017). Was Leo Strauss a Zetetic Political Philosopher? W: Yearbook of the Maimonides Centre for Advanced Studies 2017. B. Rebiger (ed.). Berlin/Boston: De Gruyter.

Botwinick, A. (2011). Michael Oakeshott's Skepticism. Princeton: Princeton University Press.

Burns, T.W., Frost, B.-P. (eds.) (2016). Philosophy, History, and Tyranny: Reexamining the Debate between Leo Strauss and Alexandre Kojeve. Albany: State University of New York Press.

Coats, W.J., Jr. (2000): Oakeshott and His Contemporaries. Selinsgrove: Susquehanna University Press.

Devigne, R. (1996). Recasting Conservatism: Oakeshott, Strauss, and the Response to Postmodernism. New Haven: Yale University Press.

21 Voegelin pisze też, że tym celem jest „spiritual augmentation of existence” (Voegelin, 2000, s. 146), ",augmentation of the Logos in [...] soul” (Voegelin, 2000, s. 149). 
Diels, Hermann/Kranz, Walther (eds.) (1985): Die Fragmente der Vorsokratiker. Griechisch und deutsch. Bd. 1-3. Zürich (cyt. jako DK).

Drury, S. (1994). Debate With Leo Strauss. W: Idem: Alexandre Kojève: The Roots of Postmodern Politics (143-160). New York: St. Martins Press.

Emberley, P., Cooper, B. (2004). Faith And Poltical Philosophy: The Correspondence between Leo Strauss and Eric Voegelin, 1934-1964. Columbia and London: University of Missouri.

Gerencser, S.A. (2000). The Skeptic's Oakeshott. London: Palgrave Macmillan.

Grant, G.P. (1964). Tyranny And Wisdom: A Comment on the Controversy Between Leo Strauss and Alexandre Kojève. Social Research, 31 (1), 45-72.

Kleszcz, R. (2011). Pascal a problem sceptycyzmu. Analiza i Egzystencja, $15,139-160$.

Kubok D. (2018). Conversation and Conservation: Two Kinds of Anti-Dogmatic Criticism in the Philosophy of Politics and their Antecedents in Ancient Greek Forms of Skepticism and Fallibilism. W: D. Kubok (ed.), Thinking Critically: What Does It Mean? The Tradition of Philosophical Criticism and Its Forms in the European History of Idea (73-92). Berlin/Boston: De Gruyter.

Laursen, J.Ch. (2005). Oakeshott's Skepticism and the Skeptical Traditions. European Journal of Political Theory, 4, No. 1, 37-55.

Leszczyński D. (2012). Realizm i sceptycyzm. Studia analityczne. Wrocław: Wydawnictwo Uniwersytetu Wrocławskiego.

Marquard, O. (1994). Rozstanie z filozofia pierwszych zasad. Studia filozoficzne. Przeł. K. Krzemieniowa. Warszawa: Oficyna Naukowa.

McAllister, T.V. (1997). Revolt Against Modernity. Leo Strauss, Eric Voegelin, and the Search for Postliberal Order. Lawrence: University Press of Kansas.

Morrissey, M.P. (1994). Consciousness and Transcendence: The Theology of Eric Voegelin. Notre Dame, Indiana: University of Notre Dame Press.

Oakeshott, M. (1999). Filozofia polityki. Przeł. A. Lipszyc. W: Idem: Wieża Babel i inne eseje. Wybrał i wstępem opatrzył P. Śpiewak. Warszawa: Wydawnictwo "Aletheia".

Oakeshott, M. (1962). Rationalism in Politics and other essays. London: Methuen \& Co Ltd.

Oakeshott, M. (1993). Religion, Politics and the Moral Life. T. Fuller (ed.). New Haven and London: Yale University Press.

Oakeshott, M. (1996). The Politics of Faith and the Politics of Scepticism. T. Fuller (ed.). New Haven: Yale University Press.

Orsi, D. (2015). Michael Oakeshott's Skepticism. The European Lagacy, 20, 6, 575-590.

Pascal, B. (1972). Myśli. Przeł. T. Żeleński (Boy). Warszawa: Pax. 
Pascal, B. (1962). Rozprawy i Listy. Przeł. T. Żeleński-Boy i M. Tazbir. Warszawa: Pax.

Patard, E. (ed.) (2008). „Restatement”, by Leo Strauss (Critical Edition). Interpretation: A Journal of Political Philosophy, 36 (1), 3-100.

Peirce, Ch.S. (1931-1958): The Collected Papers. Vols. I-VI. Charles Hartshorne and Paul Weiss (eds.). Cambridge, MA: Harvard University Press 1931-1935; Vols. VII-VIII. Arthur W. Burks (ed.). Cambridge, MA: Harvard University Press 1958.

Plantinga, A. (1992). Dogmatism. W: J. Dancy, E. Sosa (ed.), A Companion to Epistemology. Oxford UK: Blackwell Publishers, 108-109.

Platon (1999). Dialogi. T. II. Przeł. W. Witwicki. Kęty: Antyk.

Sekstus Empiryk (1958). Sexti Empirici Opera. H. Mutschmann (rec.). Vol. I, Pyrrhoneion hypotyposeon libros tres continens, J. Mau (cur.). Leipzig: Teubner 1912 (repr. Leipzig 1958).

Sextus Empiricus (1990). Outlines of Pyrrhonism. Transl. R.G . Buffalo: Prometheus Books.

Stefanini, L. (1932-1935). Platone. 2 vols. Padova: Cedam.

Strauss, L (1945). Farabi's Plato. W: Louis Ginzberg: Jubilee Volume (347393). New York: The American Academy for Jewish Research.

Strauss, L. (1983). Studies in Platonic Political Philosophy. Chicago: University of Chicago Press.

Strauss, L. (1995). Prześladowanie i sztuka pisania. W: Idem: Sokratejskie pytania. Wybrał i wstępem poprzedził P. Śpiewak, przeł. P. Maciejko. Warszawa: Fundacja "Aletheia”.

Strauss, L. (2000a). On Tyranny. Revised and Expanded Edition. Including the Strauss-Kojève Correspondence. V. Gourcevitch, M.S. Roth (eds.). Chicago and London: University of Chicago Press.

Strauss, L. (2000b). Restatement on Xenophon's Hiero. W: Idem: On Tyranny. Revised and Expanded Edition. Including the Strauss-Kojève Correspondence. V. Gourcevitch, M.S. Roth (eds.). Chicago and London: University of Chicago Press.

Strauss, L. (2006). Reason and Revelation (1948). W: H. Meier, Leo Strauss and the Theologico-Political Problem. Transl. M. Brainard. Cambridge: Cambridge University Press.

Tigerstedt, E.N (1977). Interpreting Plato. Stockholm: Almqvist \& Wiksell. Tseng, R. (2003). The Sceptical Idealist: Michael Oakeshott as a Critic of the Enlightenment. Exeter: Imprint Academic.

Voegelin, E. (2000). Order and History, Vol. 3, Plato and Aristotle. W: D. Gerimo (ed.), The Collected Works of Eric Voegelin, Vol. 16. Columbia: University of Missouri Press.

Webb, E. (1981). Eric Voegelin: Philosopher of History. Seattle and London: University of Washington Press. 
Kilka uwag o modelach zetetycznych w filozofii polityki

Webb, E. (1978). Eric Voegelin's Theory of Revelation. The Thomist, 42, 95-122.

Wood, N. (1959). A Guide to the Classics: The Skepticism of Professor Oakeshott. Journal of Politics, 21, 647-662.

Ziemińska, R. (2013). Historia sceptycyzmu. W poszukiwaniu spójności. Toruń: Wydawnictwo Naukowe Uniwersytetu Mikołaja Kopernika.

\section{Copyright and License}

This article is published under the terms of the Creative Commons Attribution - NoDerivs (CC BY- ND 4.0) License http://creativecommons.org/licenses/by-nd/4.0/ 